\title{
GENDER VIOLENCE AS A POSSIBLE OBJECT OF SOCIALIZATION FOR BOTH SEXES

\author{
Hermína Mareková
}

\begin{abstract}
There are countless theories and models of socialization. All of these theories agree on one thing: it is a process, during which people pass on and absorb social values and norms, including the norms that apply to gender. Socialization is not a one-way process, in which our children acquire information from our "adult" world. It is rather a two-way process.

Children socialize with each other in everyday interactions - both at home and away from home. In the theories of socialization at school, from the point of view of interaction, the focus is on the microsocial area, i.e the interaction between subjects. The basic concept of all interactions is therefore communication between the subjects. The individuals have a common set of symbols - speech - at their disposal and are confronted with the expectation of a stabilized behavior. The occurrence of violence in the child's family and in the social environment has significant socializing and educational effects, in a negative sense.
\end{abstract}

UDC Classification: 304, DOI: https://doi.org/10.12955/pss.v1.64

Keywords: socialization, gender, violence, children, family.

\section{Introduction}

There are myriads of various theories and models of socialization, but they all agree that it is a longterm process, within which people absorb and pass on social values and norms, including norms such as gender. Socialization is not just a one-way process in which our children acquire information from our "adult world". Children socialize in everyday interactions. The family has always existed primarily so that people can take care of their offspring. It is a unique and irreplaceable institution, it is the first example of society that the child encounters, the first socializing environment. From the biological point of view, the family serves to sustain humanity and it should be the most beautiful place in the world, where one likes to return, where one spends the good and the bad times. In recent years, we have witnessed many changes in the family, which have been even more emphasized after social changes in Slovakia. Our society was used to a directive management by the state, where the individual was supposed to meet the requirements of society, to be faithful to the ideology and, as a reward, they did not have to worry about their needs; everything was provided by society. Such management divested people of personal responsibility for their actions, but, after a change in social order, we suddenly want people to be personally responsible in every field of their social and personal life. However, quantitative statistics do not tell very much about what is going on behind the closed doors of households, especially about domestic violence. As a result of social changes, the emergence of an anomic state (in sociology, anomy is the state of decomposition of the social order, the moral and cultural norms), social morality loosens and people begin to behave deviantly. It is a status of inadequate social integration.

We live at a very fast pace, not having enough time for anything. The numbers in divorce statistics are increasing. The number of children living with one parent - often their mother - is rising. A new phenomenon, the feminization of poverty, is on the rise, too. Aggressive, violent behavior in the family and between partners remains behind the closed household doors. Even if the public learns about it, there has not been much willingness in society to interfere in "private" problems of families. The child in families with social pathology does not experience and therefore does not perceive mutual expressions of respect. On the one hand, society recognizes the basic socializing role of the family and expects the family to fulfill all the responsibilities it has. On the other hand, it is unable to provide adequate assistance to troubled families.

One of the reasons why we are dealing with this issue is that the number of families with social pathology, violence against women (often witnessed by minors) and, more recently, even abuse of the elderly and often disabled people, is increasing. We like to say that we create the future of a nation in the present, so the question is what future we are actually creating when the young generation is growing up and socializing amidst violence, in an environment where violence is tolerated to some extent and sometimes even neglected. Everyone probably agrees that this is not a very good example for the young people and their future relationships. Values of an ethical nature, such as freedom,

\footnotetext{
${ }^{1}$ Danubius University, Sládkovičovo, Slovakia, hermina.marekova@gmail.com
} 
power, truth, justice, kindness, are apparently not relevant for a "good" life. In the way of life, there is a significant reduction in the values giving a purpose and meaning to human existence, especially a reduction of ethical values to values of a tangible nature, such as possessions, unhealthy consumerism that are changing the way of thinking from "to be at any price" in favor of "to have at any price." (Kusín, Šebestová, Drábiková, 2015: 11).

\section{Socialization and the theories of gender socialization}

"Society has shaped us and put in us sympathy and understanding that prescribe our behavior and which react with great energy when we resist obeying their commands. Their value is the moral conscience and it also expresses it: when our conscience speaks, it is society that speaks" (Durkheim, 1984: 47).

Socialization is not a one-way process during which our children acquire information from our adult world, but rather a two-way process. Children socialize with each other in everyday interactions, both at home and away from home. In theories of socialization at school, from the point of view of interaction, the focus lies in the microsocial area: interactions between subjects. The structuralfunctionalist theories look at socialization from the perspective of the outside viewer. The interactionist theories analyze the problems of socialization from the perspective of the participants themselves. Thus, when socializing at school, the process of communication between subjects is monitored. The individual uses a common set of symbols - speech - and is confronted with the expectation of a stabilized behavior. The basic notion of all these theories is therefore interaction. Such an interaction model represents a balance between the two partners in the role-taking and role-making process (Goffman, 1961).

Under the creation of identity in terms of interactionist theories, Mead (1968) understands the ability of an individual to reflect on itself and become an object to itself. Identity arises only, in the process of communication, when an individual can see through its counterpart's eyes and form an image of itself. One of the seven principles, on which symbolic interactionism is based, is the assertion that it is the interaction with another person that makes a human an individual. It introduces the term interactive action, which can be understood as meaningful, interrelated activities of at least two people (Mead, 1968, in: Ondrejkovič, 2004).

During early socialization, children create groups on the basis of gender, with an emphasis on gender differences at the expense of similarities. Since their childhood, boys are inculcated with independence, assertiveness, fighting spirit, curiosity - values that are highly appraised in society. On the other hand, girls are brought up to be dependent, passive, domestic - traits that are being devalued in our society. Androcentrism is cultivated in them, i.e. the idea that men are superior to women and the whole world is standardized according to this idea.

\section{Psychoanalytic theories}

These theories include, among others, the theory of identification, introduced by such personalities as Sigmund Freud, Karen Horney, Erik Erikson, Clara Thompson, Nancy Chodorov, etc. Children undergo their personal development in approximately the same way up to four years of age. After this age they unconsciously begin to imitate their parents in accordance with their sex. The central problem with the process of acquiring gender is that boys must mentally separate from their mothers, while girls do not experience this separation.

\section{Theories of social learning}

The leading figure in this theory is Albert Bandura. According to him, children acquire their gender in two ways: by empowering - that is by rewards for gender-appropriate behavior and punishment for gender-inappropriate behavior, and by modeling.

\section{Cognitive theories - gender schema theory, theory of optical glasses of culture}

Represented by: Jean Piaget, Lawrence Kohlberg, Sandra Bem.

Children absorb gender and gender stereotypes as part of their mental efforts to find an order in the social world that surrounds them. To evaluate sensory information, children create schemes, categories that allow them to observe the information and organize their experiences based on stable patterns as well as regularity. Gender is one of the earliest schemes created due to the fact, among other things, that it represents a relatively stable and easily recognizable category with physical characteristics. 
According to the "optical glasses of culture" theory, which also includes some features of the theory of social learning, children are socialized to adopt gender optics, to accept the assumptions of masculinity and feminity that are valid in society. This enculturation takes place through institutionalized practices, as well as by covert signals of values and relevant differences that guide the lives of children from their birth (Renzetti, Curran, 2003).

The question is whether non-sexist socialization is possible at all. According to some authors, purposeful non-sexist socialization by parents has a positive impact on children (Renzetti, Curran, 2003). The imbalance between women and men is one of the possible causes of the occurence and even tolerance of violence against women in society. Men, as a social category, have the right to control the behavior of women. In a couple consisting of a man and a woman, the man is the authority, power and reason, while the woman is the more sensitive, submissive, that is, the weaker one, all on the basis of the stereotyped division of tasks. Such a division of tasks creates, albeit unconsciously, an imbalance of power (Mareková, 2019).

The occurence of violence and experiences of abuse have significant socializing and educational effects in a negative sense.

Such experience then becomes a signal to children and young people that violence against women is a tolerated part of our social life, as well as in male-female relationships. In the process of socialization and upbringing, this leads to the perception of violence as a common means of imposing someone's will. According to Durkheim, coercion is an expression of objectivity. It is a sign of social phenomena, that is both education and socialization (Durkheim, 1984).

Gender violence is the subject of socialization within the process of interaction during socialization.

The study of the process of socialization without a scrutiny of the increasing importance of violence in society, including the gender-based one, is unthinkable. Some authors even refer to our century as a century of violence. Liberalization in schools, lack of social control and other negatives contribute to nonconformist behavior, deviation. The most significant characteristics of our time are instability, uncertainty, fragility of mutual relations, anomy of society after the change of social order.

The current state of society, an increase in violence at every stage, are contributed by the processes of socialization and education issues, among other things. The process of socialization, which has been dealt with in countless theories, is being tackled by a new direction - radical constructivism (Mareková, 2019). From the point of view of socialization, it is essential that each human creates reality and thus itself. The factors that mediate the process of socialization can be regarded as socializing factors. Increasingly important for the socialization process are the results of molecular biology, pointing to the biological, hormonal and especially genetic conditioning of human behavior, and we can say with certainty that the new epistemological situation requires a new model that could replace the classical model of social sciences that studies humans as isolated from nature (Ondrejkovič, 2004). Among the new theories, we can mention the very interesting theory of Ilya Prigogine, which deals with the problems of information transfer, among other things. He derives more general consequences from certain physical theories and draws conclusions from his research about the form of the paradigm of contemporary science, thus creating a new epistemiological situation. The classical model of the world that isolates humans as rational beings from nature must be replaced by a new model in which the natural world will be rehabilitated. Based on his research on irreversible processes, especially in non-isolated systems (A system is understood as an organized set of entities connected with some kind of link, relationship among them. It can be a social system or a biosystem.), Prigogin concluded that beyond a certain threshold of instability, there emerges a sort of self-organization, which is a spontaneous activity called dissipative organization. It is a structure that is created, functions and is maintained through the exchange of energy with the outside world (Nicolis and Prigogine, 1987).

\section{The Role of Gender-Sensitive Education in Socialization}

The process of socialization without considering the increasing importance of violence (including gender-based violence) in society is unimaginable, because socialization is related to the whole complex of living conditions that have a decisive influence on the development of the individual.

Recently, we have witnessed a shift in the transmission of culture (socialization) within the family. Over a very long period of time, within the family system, culture has been transmitted vertically i.e. 
from an older family member to a younger one. Nowadays the transmission is horizontal. This represents a great burden for parents, because they have to fight for attention in raising their children with their friends. To a certain extent, it contributes to degradation of said transmission. Without the initiation processes and expectations, the young generation is very happy to live according to the motto carpe diem.

Elimination of gender stereotypes from education and promoting a gender-sensitive approach during socialization would contribute to change in primary prevention and elimination of the root cause of gender-based violence. Secondary prevention of gender-based violence is based on creating the conditions to provide effective assistance to women who have experienced or are experiencing such violence. It would be appropriate to include the issue in the curriculum of secondary schools during the preparation of professionals in the fields of medicine, nursing, social work, counseling, law, police and psychology.

\section{Conclusion}

When we are born, we are assigned a gender based on our biological traits and, in accordance with those traits, an expected identity is determined. It is increasingly being debated, in today's rapidly changing world, if society's expectations regarding our gender identity are still important. The norms, values and expectations that are related to a given biological sex, are "assigned" to us by society. At the same time, society determines that they are the only correct standards. This ever-repeating stereotype degrades female sex and prevents women who choose traditional female role from achieving the same social status as men. And vice versa, men cannot take on the "female role" without losing their social status as men. That is why socialization on the background of domestic violence against women predetermins the reproduction of violence. In today's society, there is still no social demand for educating children about how to resolve their conflicts non-violently from an early age.

\section{References}

Buchtelová, R., Confortiová, H., Červená, V, Holubová, V., Hovorková, M. et al. (1997). Slovník cudzích slov [A Dictionary of Foreign Words]. Bratislava, Slovakia: Slovenské pedagogické nakladatel'stvo.

Durkheim, E. (1984). Erziehung, Moral und Gesellschaft [Education, Morality and Society]. Frankfurt, Germany: Suhrkamp. Goffman, E. (1961). Asylums: On the Social Situations of Mental Patients and Other Inmates. New York, USA: Garden City, Doubleday and Company.

Kusín, V., Šebestová, P., Drábiková, J. (2015). Etika v sociálnej práci a otázky l’udských práv a slobôd [Ethics in Social Work and the Issues of Human Rights and Freedoms]. Sládkovičovo, Slovakia: VŠD FSS̆.

Mareková, H. (2019). Násilie v rodine a sociálna práca. Rodové násilie (súčasné diskusie, problémy, perspektívy, výskum) [Domestic Violence and Social Work. Gender-Based Violence (Current Debates, Issues, Perspectives and Research)]. Brno, Czech Republic: MSD, Ltd.

Mead, G. H. (1968). Geist, Identität und Gesellschaft [Spirit, Identity and Society]. Frankfurt, Germany: Suhrkamp. In: Nicolis, G., Prigogine, I. (1987). Die Erforschung des Komplexen [Exploring Complexity]. Munich, Germany: Piper.

Ondrejkovič, P. (2004). Socializácia v sociológii výchovy [Socialization in the Sociology of Education]. Bratislava, Slovakia: SAV.

Renzetti, C. M., Curran, D. J. (2003). Ženy, muži a spoločnost' [Women, Men and Society]. Prague, Czech Republic: Karolinum. 